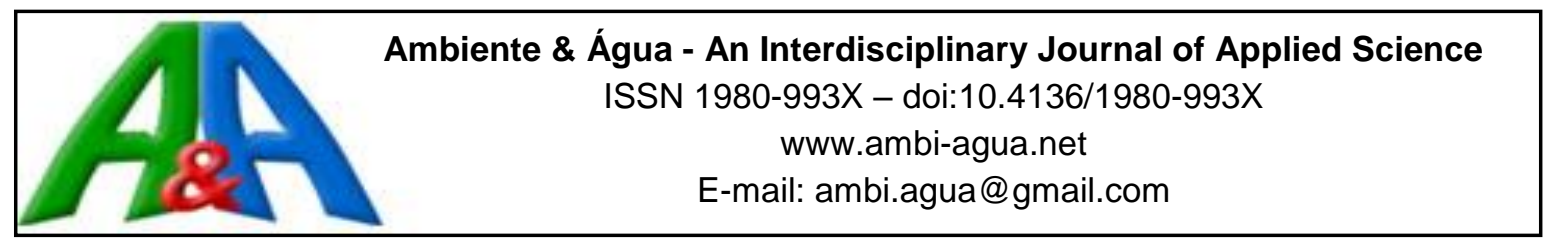

\title{
Mobile transect for identification of intra-urban heat islands in Uberlandia, Brazil
}

\author{
ARTICLES doi:10.4136/ambi-agua.2187
}

Received: 26 Sep. 2017; Accepted: 04 May 2018

\author{
Valdiney José da Silva1; Cláudio Ricardo da Silva²; Leandro da Silva Almeida²; \\ Claudionor Ribeiro da Silva ${ }^{1}$; Hudson de Paula Carvalho²; Reginaldo de Camargo ${ }^{2}$

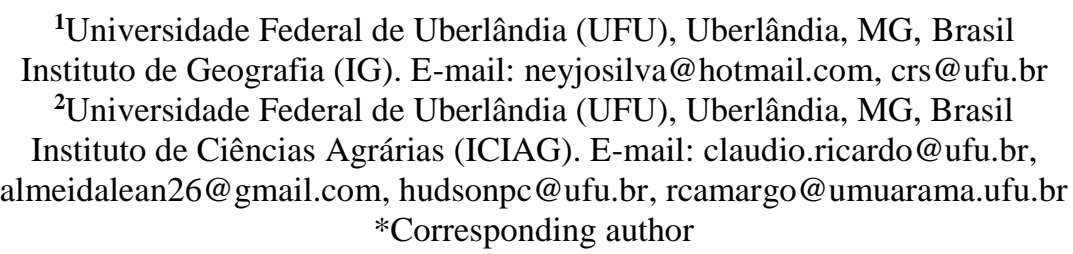

\section{ABSTRACT}

The "heat island" phenomenon is one of many serious problems caused by rapid urban growth. This study therefore sought to characterize and quantify heat islands in Uberlandia, to evaluate the seasonality of these islands (winter-summer) and to identify the effect of surface coverage on their intensity. To identify intra-urban heat islands in Uberlandia, air temperature data were collected in two seasons (winter and summer) using mobile and fixed transects seasons. Transition measurements were recorded automatically every 0.5 seconds using a carmounted thermos-hygrometer moving at an average of $40 \mathrm{~km} \mathrm{~h}^{-1}$. GPS was used to select approximately ten data points every 500 meters of each transect. Fixed weather stations measured air temperature at three sites in the region. Transect data analysis showed that the intra-urban heat islands were more intense in winter $\left(\Delta \mathrm{T}=2.2^{\circ} \mathrm{C}\right)$ than in summer $\left(\Delta \mathrm{T}=1.2^{\circ} \mathrm{C}\right)$ mainly because by reduction in atmospheric vapor in winter (dry season) and by higher rate of radiative cooling that is favored in permeable areas. The methodology used in the present study proved to be a quick and efficient way to carry out this type of monitoring.

Keywords: air temperature, urban heat island, winter.

\section{Transecto móvel para identificação de ilha de calor intra-urbana em Uberlândia, Brasil}

\section{RESUMO}

O fenômeno da ilha do calor é um dos muitos problemas graves causados pelo rápido crescimento urbano. Assim, os objetivos deste estudo foram: caracterizar e quantificar ilhas de calor em Uberlândia, avaliar a sazonalidade destas ilhas (inverno-verão) e identificar o efeito da cobertura superficial na intensidade das mesmas. Para identificar as ilhas de calor intraurbanas em Uberlândia, os dados de temperatura do ar foram coletados em duas estações (inverno e verão) usando transectos móveis e estações climáticas fixas. As medidas de transição foram gravadas automaticamente a cada 0,5 segundos usando um termo-higrometro montado em carro movendo-se a uma média de $40 \mathrm{~km} \mathrm{~h}^{-1}$. O GPS foi usado para selecionar aproximadamente dez pontos de dados a cada 500 metros de cada transecto. As estações 
meteorológicas fixas mediram a temperatura do ar em três locais da região. A análise dos dados mostrou que as ilhas de calor intra-urbana em Uberlândia foram mais intensas no inverno $\left(\Delta \mathrm{T}=2,2^{\circ} \mathrm{C}\right)$ que no verão $\left(\Delta \mathrm{T}=1,2^{\circ} \mathrm{C}\right)$ devido principalmente à redução no vapor de água atmosférico no inverno (estação seca) e pela taxa de resfriamento radiativo maior nas áreas permeáveis. A metodologia utilizada no presente estudo mostrou ser uma maneira rápida e eficiente de realizar esse tipo de monitoramento.

Palavras-chave: ilha de calor urbano, inverno, temperatura do ar.

\section{INTRODUCTION}

The urban heat island (UHI) phenomenon is characterized by higher urban temperatures relative to those of surrounding rural areas (Oke, 1973) and can cause many serious problems. Several factors contribute to the formation of heat islands including diurnal absorption and storage of heat, thermal and calorific properties and nocturnal heat emissions of construction materials, anthropogenic emissions (vehicle and pedestrian traffic), reduced evapotranspiration caused by replacing natural surface coverage with asphalt and concrete surfaces and canalizing and covering rivers and streams, and reduced heat loss due to taller buildings that decrease wind speeds and block radiation (Erell and Williamson, 2007; Rizwan et al., 2008).

UHI have also been positively correlated with population size (Oke, 1973), which determines the level of heat produced directly by people or indirectly by buildings (Rizwan et al., 2008). Urban Heat islands may also be directly related to temporary causes such as a stationary cyclones, low wind speeds, and limited cloud cover (Oke, 1973).

Not only do heat islands cause discomfort, especially in tropical cities, they also increase energy consumption, ozone levels (lower troposphere), respiratory illness and death (Rizwan et al., 2008). Furthermore, increasing urban temperatures have contributed to climate change.

Temperature differences between urban and rural areas determine the intensity of UHIs (Oke, 1973). Urban Heat island intensity $\left(\Delta T_{u-r}\right)$ is an important indicator of the degree of urbanization (Rizwan et al., 2008). It tends to be higher at night, lower or even negative during the day (Oke 1973) and seasonal (Jonsson, 2004; Yokobori and Ohta, 2009) given the rapid radiative cooling in rural areas due to favorable atmospheric conditions.

The methodologies used to determine $\Delta T_{u-r}$ involve collecting meteorological data from static-automated stations, mobile transects and by atmospheric microwave emissions in urban and rural areas (Hedquist and Brazel 2006). However, there is increasing use of remote sensing data for this study. It can be determined more accurately by using horizontally scaled sites $\left(10^{2}-10^{4} \mathrm{~m}\right)$, collecting data close to the ground (1-2 $\left.\mathrm{m}\right)$ and by measuring for days, months or years (Stewart, 2011).

According to Hedquist and Brazel (2006), mobile transects are especially useful when climatological data is limited and when automated-fixed stations are too sparse for accurate representation of urban and rural atmospheres. Fixed networks are also more expensive and subject to vandalism (Erell and Williamson, 2007). However, mobile transects are always suspect as to what they spatially represent along or adjacent to the transect routes (Hedquist and Brazel, 2006).

Although the UHI has been widely documented in much of the world, there are still few studies in medium-sized Brazilian cities. Therefore, our main objective was to verify if mobile transect methodology is efficient in the characterization of urban heat islands in Uberlandia, seeking to achieve the following specific objectives: a) to characterize and quantify the heat islands in Uberlandia, b) to evaluate heat island seasonality (winter-summer) and c) to identify the effect of surface coverage on heat island intensity. 


\section{MATERIALS AND METHODS}

\subsection{Experiment area}

Uberlandia is located in the southeast of Minas Gerais state $\left(18^{\circ} 55^{\prime} 23^{\prime \prime} \mathrm{S}\right.$ and $\left.48^{\circ} 17^{\prime} 19^{\prime \prime} \mathrm{W}\right)$. The city covers $4,115 \mathrm{~km}^{2}$ and has a $219 \mathrm{~km}$ perimeter. The economy of Uberlandia is diverse; however, wholesale distribution is especially strong given the strategic location of the city.

The climate of Uberlandia is classified as tropical climate with dry winter Aw (Köppen) with dry winters and rainy summers dominated by inter-tropical and polar systems.

Natural vegetation (Cerrado - the Brazilian savannah, forest, hydromorphic fields, lowland fields and hydrophilic fields) covers $17.7 \%$ of the municipality of Uberlandia whereas urban areas cover $4.6 \%$. Excluding the largest metropolitan centers, Uberlandia is one of the most populous regions in the country. According to the last census the city had 604,013 inhabitants (97.2\% urban, $2.8 \%$ rural). In addition, the population of the city grew at $1.8 \%$ between 2000 and 2010, whereas the populations of the surrounding region and state grew at $1.5 \%$ and $0.9 \%$, respectively. The city comprises distinct socioeconomic regions (Figure 1). Most upper-class neighborhoods, recreation clubs and private universities are concentrated in the southern sector. Lower-class neighborhoods comprise the western and eastern regions, and the airport and industrial district are located in the northern region. The downtown is home to stores, banks, a bus station and interspersed residential areas. The altitude of the municipality ranges from 750 to $900 \mathrm{~m}$ and the city is crossed by the Uberabinha River from east to west. Streams in downtown Uberlandia have been channelized. Consequently, flooding is frequent during heavy summer rainfall.

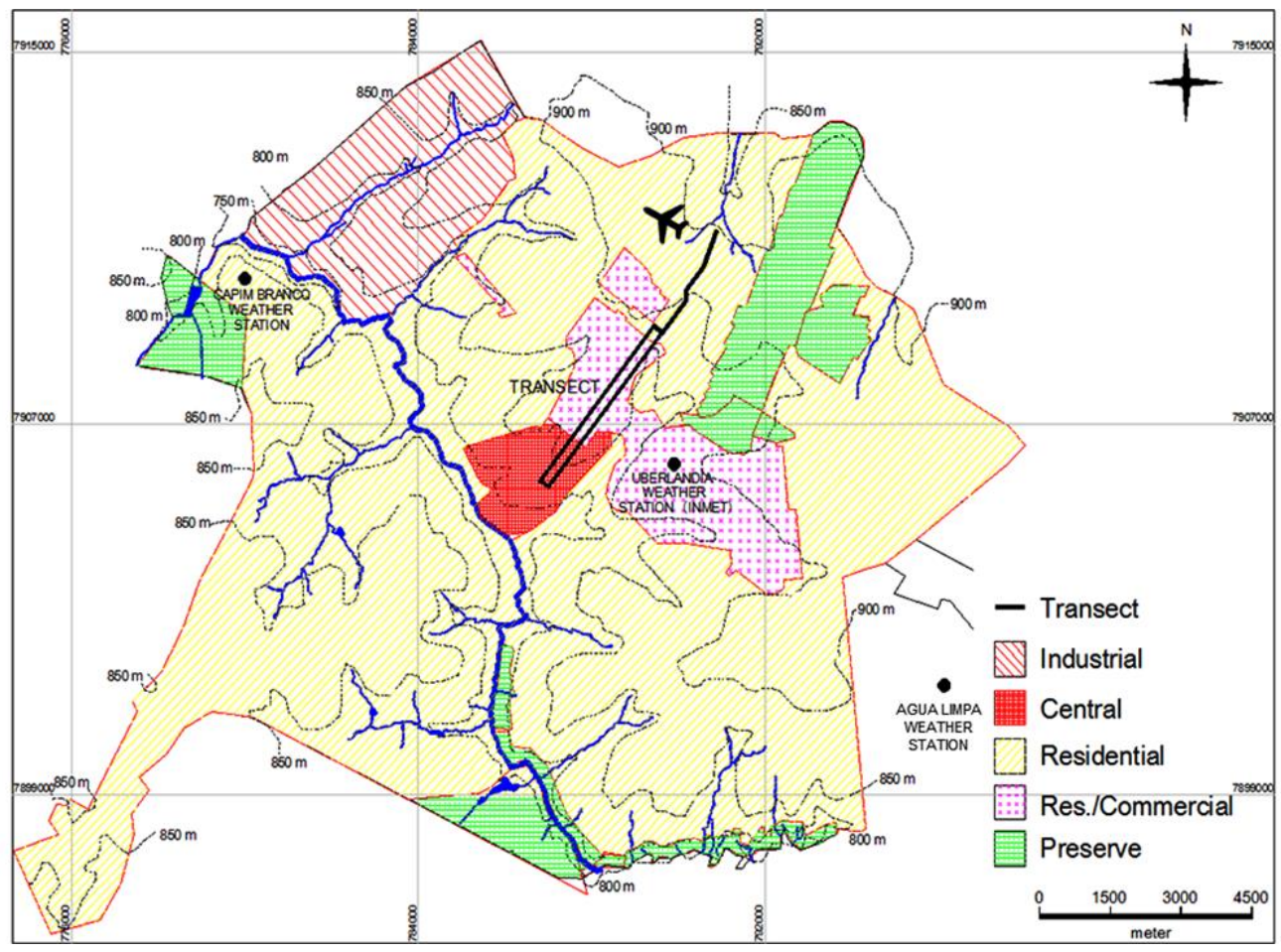

Figure 1. Characterization of urban land use and the mobile transect route.

\subsection{Meteorological data collection}

Temperature was measured along a straight transect from the periphery of the city to the center to evaluate how urban land use in Uberlandia influences air temperature. Mobile transects were first used to study urban temperature conditions by Oke (1981). Since then, studies have employed this technique (Hedquist and Brazel, 2006; Stewart, 2011). 
The city urban area is large $\left(135 \mathrm{~km}^{2}\right)$ and mobile transects across its entire area are difficult because of large traffic volumes and long time-sampling issues. Thus, the route was chosen based on topography and soil cover diversity (Figure 1). Heat islands are well-defined at evening hours (Amorim et al., 2015). Thus, measurements were taken at 20h (local time) on the 15th, 20th and 21st of August, 2012 (winter) and on the 26th, 27th and 28th of February, 2013 (summer). Wind speeds during the transect were 0.6 to 1.4 and 0.0 to $1.0 \mathrm{~m} \mathrm{~s}^{-1}$, during winter and summer, respectively.

Air temperature was measured with a thermo-hygrometer (mod.HMP $45^{\circ} \mathrm{C}$, Vaisala, accuracy: $\pm 0.4^{\circ} \mathrm{C}$, range: $-24 \sim 38^{\circ} \mathrm{C}$ e $\pm 2 \%$ between $0 \sim 90 \%$ ) coupled to an automatic datalogger (mod. CR10X, Campbell Scientific) programmed to take readings every $0.5 \mathrm{~s}$ and store one on average per second. Before taking the temperature measurements, the average temperature readings from the sensor were checked against the temperatures measured by an automated weather station belonging to the National Meteorological Institute (INMET) located near downtown Uberlandia at the Geography Institute of the Federal University of Uberlandia (18 54'66" S, 48¹5'00" W, $869 \mathrm{~m}$ above sea level).

The thermo-hygrometer was housed in a meteorological structure located $1.5 \mathrm{~m}$ above the ground and lateral to and $30 \mathrm{~cm}$ above the vehicle roof. To avoid interference from heat emissions, only measurements taken at speeds greater than $40 \mathrm{~km} \mathrm{~h}^{-1}$ were considered (similar to a study by Wong and $\mathrm{Yu}, 2005$ ). Time and geographic coordinates were recorded (Etrex portable GPS - Garmin) at the same time as the meteorological measurements and used to discard data points when the vehicle was stopped (e.g. stoplights).

Traversing the route $(6.5 \mathrm{~km})$ took approximately $30 \mathrm{~min}$. Air temperature and humidity were measured on both outbound and return routes to make a more accurate temporal adjustment of nocturnal cooling rates over the area. Additionally, an adiabatic gradient $\left(-0.65^{\circ} \mathrm{C} / 100 \mathrm{~m}\right)$ was used to adjust the temperature data to compensate for altitude-related temperature differences along the route. After data collection, averages were calculated for every $500 \mathrm{~m}$ of the transect. Differences in air temperature $(\Delta \mathrm{T})$ and absolute humidity were then calculated relative to corresponding values in the city center.

The terms intra-urban heat island (IUHI) and intra-urban heat intensity $\left(\Delta T_{u r b-s u b}\right)$ were used because the transect had little contact with rural areas and to avoid a debate over whether this transect was large enough to properly assess the UHI. These terms were also used by Erell and Williamson (2007) and Yokobori and Ohta (2009).

In addition to transect measurements, hourly air temperature observations were made on the days of the transects using an INMET weather station located in an urban area $2.5 \mathrm{~km}$ from the city center. Two other weather stations were used (Mod. Vantage Pro2 Plus, Davis), accurate to $\pm 0.5^{\circ} \mathrm{C}\left(-40 \sim 65.5^{\circ} \mathrm{C}\right)$ for air temperature and $\pm 3 \%$ for relative humidity. One station was located in a suburban area (Capim Branco farm, $8 \mathrm{~km}$ from the city center) and the other in a rural area (Agua limpa, $21 \mathrm{~km}$ from the city center) of Uberlandia. Before the experiment, readings from these weather stations were checked against data from a National Institute of Meteorology (INMET) weather station.

\subsection{Land cover classification}

Similar to Yokobori and Ohta (2009) aerial photographs were used to classify the land cover conditions in a swath extending $150 \mathrm{~m}$ to either side of the transect. These aerial photographs were geometrically corrected to UTM Zone 22, Datum WGS84. A GIS computer program (Envi 4.8, ITT Corporation) was used to identify objects in the images using object segmentation and classification techniques. Segmentation involves subdividing an image into segments or neighboring pixel groups with similar attributes such as reflectance, texture and color. Segmentation usually comprises three steps: (1) defining the segmentation scale (Scale 
Level), (2) merging the segments (Merge Level) and (3) classifying. Five classes were used in this study: roads and parking lots, buildings, green areas (trees and shrubs), bare soil and undefined areas. Scale and merging were empirically determined to be 90 and 95, respectively.

Figure 2 shows the percentages of each class along the transect. Construction (buildings, roads and parking lots) covered most of the area (70.6\%). Nevertheless, construction diminished significantly $5.0 \mathrm{~km}$ from the city center where it was replaced by bare soil and grassy vegetation. With these images, the percentage of impermeable areas was also determined.
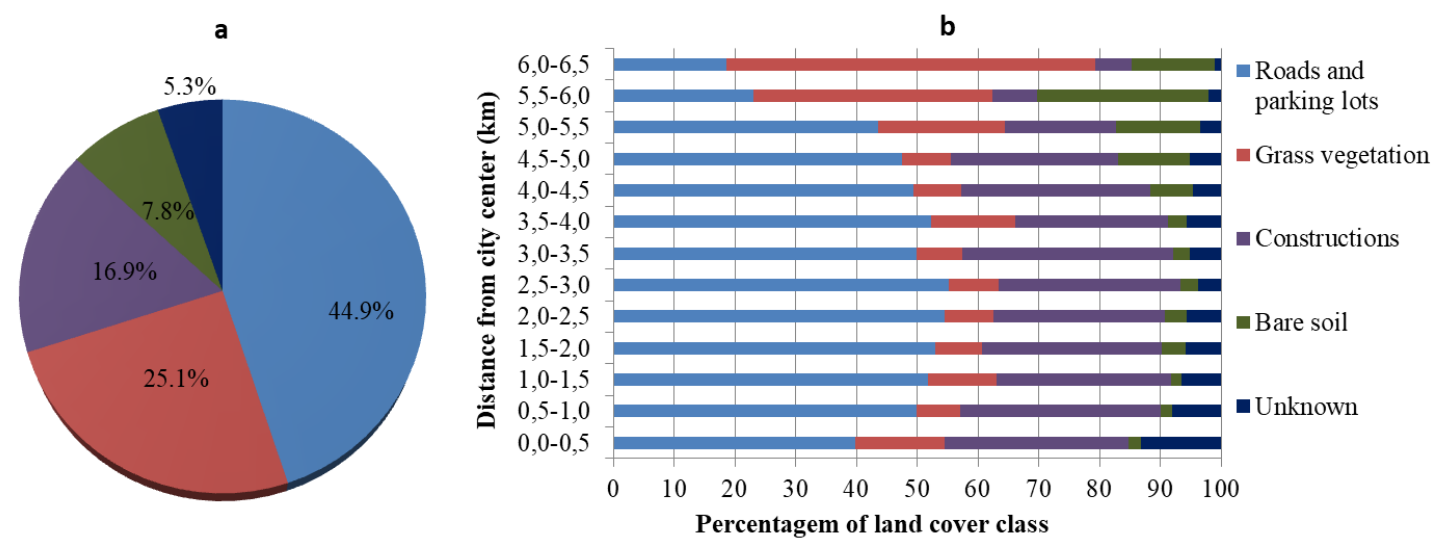

Figure 2. Average percentages of each class land cover: (a) total and (b) along the transect.

\section{RESULTS AND DISCUSSION}

Figure 3 shows the mean air temperature and absolute humidity along the transect (from the center of the city) in summer and winter on the three evaluation days of each season. Our methodology showed that IUHI existed in both winter and summer, even though there was no characteristic air temperature "spike" at the center point, as suggested by Oke (1973). The intraurban heat island intensity $\left(\Delta T_{u r b-s u b}\right)$ was $2.2^{\circ} \mathrm{C}$ in the winter and $1.2^{\circ} \mathrm{C}$ in the summer on the days studied. Most cities investigated in tropical regions showed higher IUHI in the dry season (Jonsson, 2004). In Campina Grande, Silva et al. (2010) found that high $\Delta T_{u r b-s u b}$ was observed during the representative month of the dry season. They are most frequent during the dry season when it is likely that low rural thermal admittance of dry soils combines with relatively low air moisture to cause rapid cooling rates at the rural site throughout the night.

The influence of urban development on humidity has been studied much less intensively than UHI phenomenon. Humidity can be measured by different forms (i.e., dew air point temperature, water vapor pressure, relative humidity). In this paper, absolute humidity was chosen because it is possible to quantify the mass of water present in the air. Hedquist and Brazel (2006), in Phoenix, found higher dew air temperature points in rural areas in summer because of evapotranspiration from irrigated rural areas. In our study, there was minimal humidity variability along the transect but mean values for absolute humidity in summer were about triple that of those observed in winter because of the rainy season.

With respect to observed air temperature differences among fixed weather stations (Figure 4), they were greater at night and in winter, especially from $19 \mathrm{~h}$ to $23 \mathrm{~h}$ and minimum diurnally. During the day, the low evapotranspiration in rural areas due to the low soil moisture reduced evaporative cooling. In summer, the differences were lower but persisted even during the day. The lowest air temperature values were recorded at Agua Limpa (rural) followed by Capim Branco and INMET. Also note that during the summer Agua Limpa station presented the lowest temperature values throughout the day. The INMET (urban) station only shows higher values at night (summer).

\section{IPABH}

Rev. Ambient. Água vol. 13 n. 4, e2187 - Taubaté 2018 


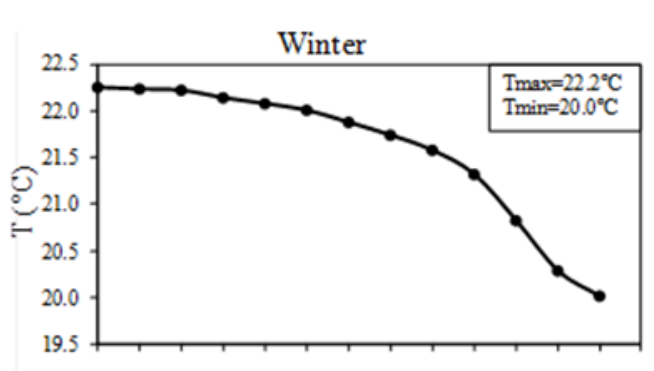

a
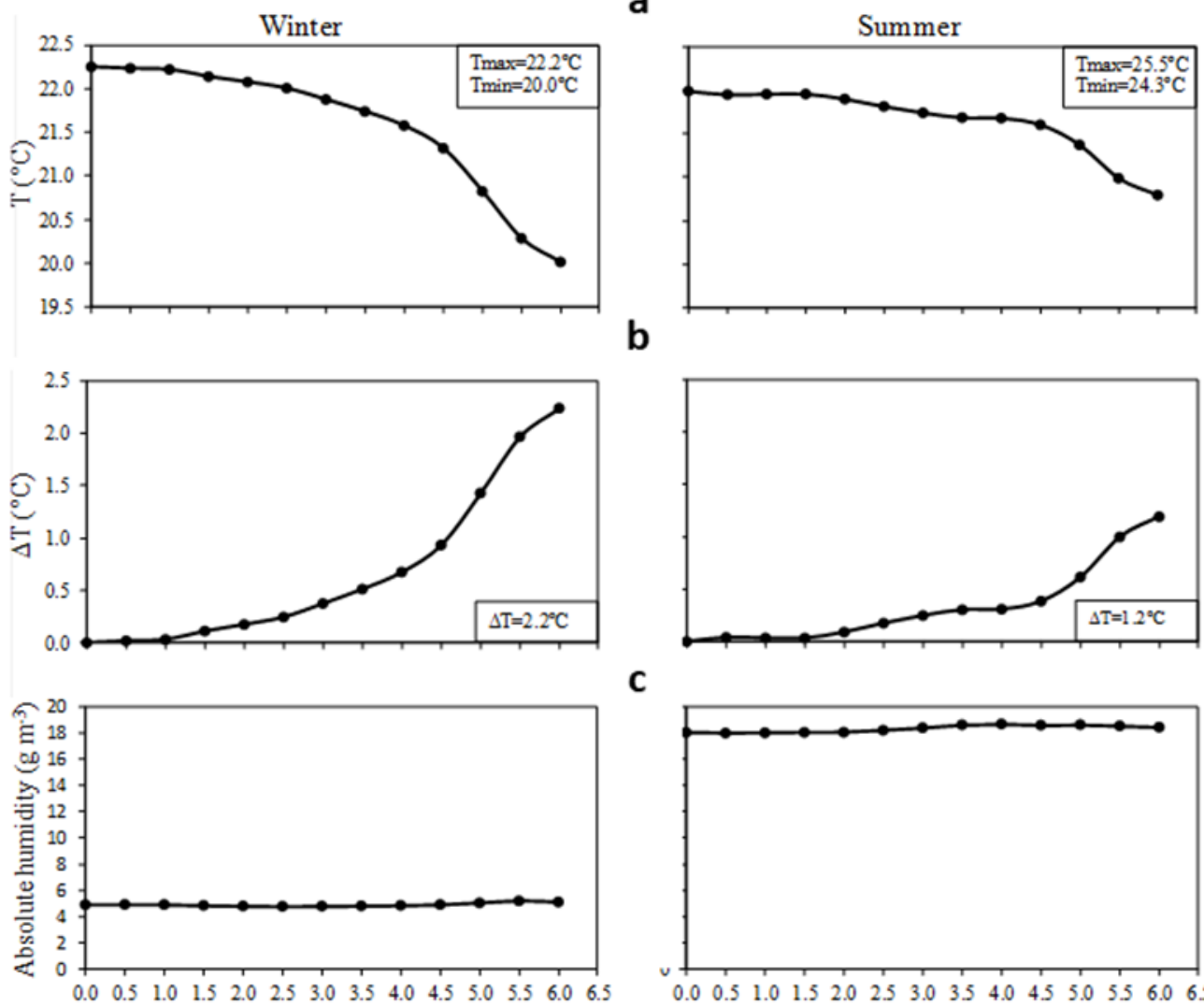

C

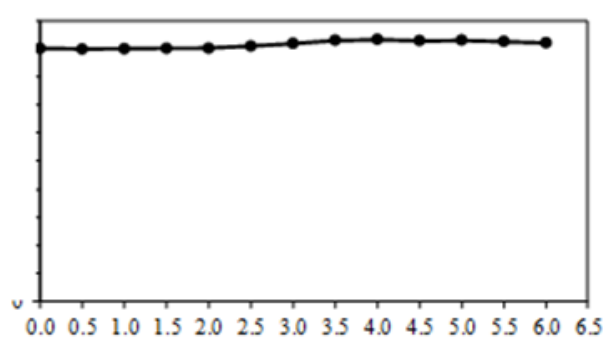

Figure 3. a) Average temperature (T), b) Air temperature variation $(\Delta T)$, c) Absolute humidity at every 500 meters, starting from the city center (winter, 2012 and summer, 2013) in Uberlandia, Brazil. Each point represents the average of 30 measurements.
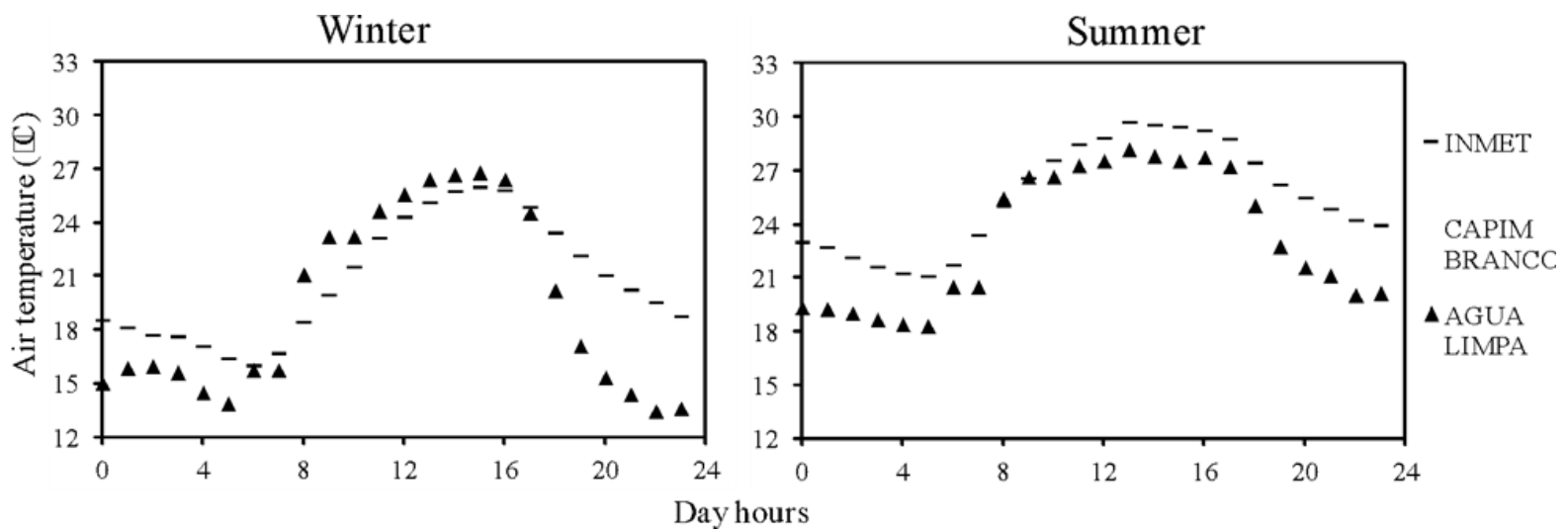

Figure 4. Hourly air temperature between fixed weather stations: urban (INMET), suburban (Capim Branco) and rural (Agua limpa) in summer and winter in Uberlandia, Minas Gerais. Each point represents the average of 36 measurements.

In winter, during daytime hours ( 8 to $16 \mathrm{~h}$ ), the air temperature was similar between the stations although the INMET station had slightly lower values. At night, the drop in air temperature was high at Agua limpa station and a little less for Capim Branco station. Thus, in winter and at night, the air temperatures differences are enlarged. By the time the transect was made (20h), the intensity $\Delta T_{\text {urb-rur }}$ were $5.8^{\circ} \mathrm{C}$ and $3.5^{\circ} \mathrm{C}$ for winter and summer, respectively. However, considering only INMET and Capim Branco stations (i.e., intra-urban area), $\Delta T_{u r b-s u b}$ were $1.9^{\circ} \mathrm{C}$ and $1.0^{\circ} \mathrm{C}$ (winter and summer, respectively), which was close to that observed with 
the mobile transect. Although $\Delta T_{u r b-s u b}$ were higher in winter, they were also present both day and night in the summer. Higher urban air temperatures in the summer occurring with higher absolute air humidity inevitably aggravate thermal discomfort (Silva et al., 2010).

In the transect on the days evaluated (Figure 1a), both summer and winter air temperatures at $20 \mathrm{~h}$ decrease gradually from the city center to $4.5 \mathrm{~km}$ and more drastically thereafter. This matches with surface cover changes (Figure 2) from impermeable (e.g., buildings, roads, parking lots) to permeable (e.g., vegetation and bare soil). This suggests that land use is crucial in determining urban climate. The correlation between the percentage of impermeable area and air temperature was linear (Figure 5). Despite greater data dispersion in winter, regression was more sensitive as indicated by the greater angular coefficient and lower linear coefficient.

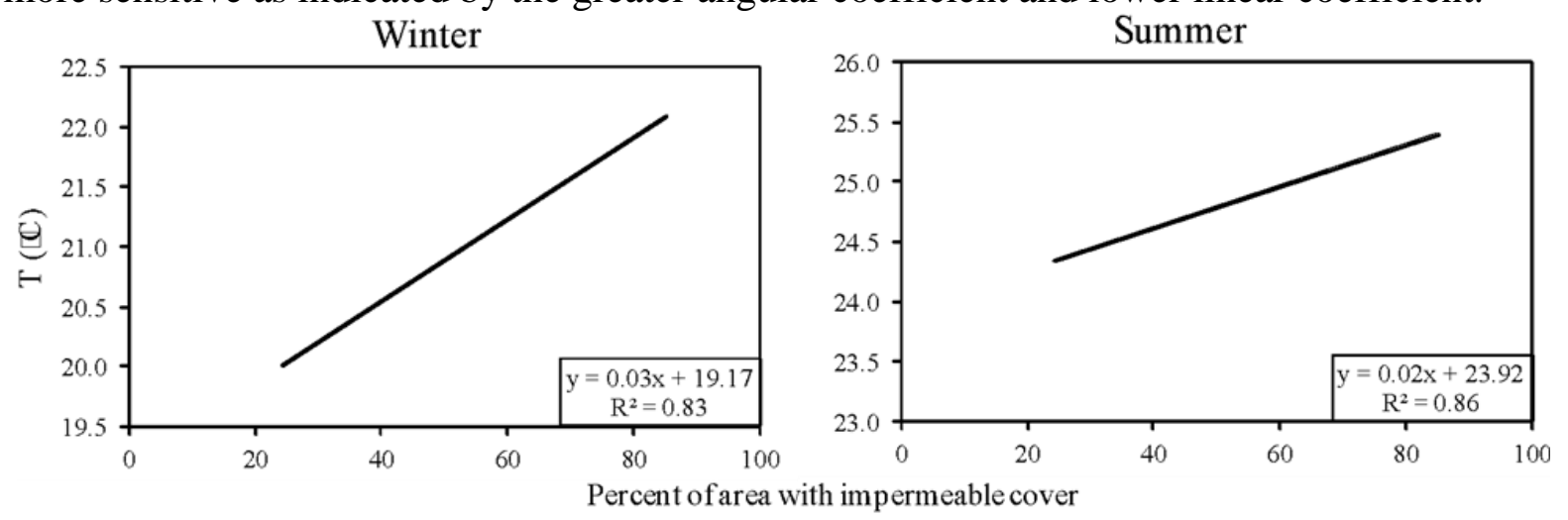

Figure 5. Relationship between the percentage of impermeable cover land and the average air temperature during transect measurements. Each point represents the average of 30 measurements.

Many studies have shown the influence of surface cover type on environmental temperature variation (Jonsson, 2004; Yokobori and Ohta, 2009; Hart and Sailor, 2009). During the day, impermeable areas absorb great amounts of solar radiation. Additionally, these areas do not allow evaporation, which causes surface temperatures to rise leading to greater sensible heat emissions and infrared radiation to the adjacent air layer. This in turn causes air temperatures in the urban center to rise during the day and night (Asaeda and $\mathrm{Ca}, 2000$ ). The water in a permeable surface acts as a thermal regulator (Hart and Sailor, 2009). When the water content of the permeable layer is sufficiently high, almost three-fourths of solar radiation can be eliminated through the latent heat of evaporation. Hart and Sailor (2009) also report that state that surface cover is the most important characteristic differentiating warmer regions from cooler ones and emphasize the impact of parks and green areas on urban temperature variation.

Sun et al. (2009) states that increasing vegetated areas in urban settings minimizes the effect of heat islands. However, urban vegetative cover is generally declining globally, inevitably intensifying UHI effects. Uberlandia is a mid-sized city with just $6.6 \mathrm{~m}^{2}$ of green space per inhabitant, which is well below the recommended $15 \mathrm{~m}^{2}$ per inhabitant (Toledo et al., 2009). Thus, constant and systematic temperature monitoring is necessary throughout the urban area to identify areas with critical temperatures and propose mitigating measures.

In addition to increasing permeable space, trees could also be planted in the streets, which could cool the air via evapotranspiration, filter pollution and provide shade. The benefits provided by trees can be even greater if they are planted around buildings. Hoyano (1988), for example, showed reductions of up to $20^{\circ} \mathrm{C}$ on shaded walls.

Other solutions might include adding lighter-colored pigment to pavement or using porous pavement that allows water infiltration and evaporation. Light colors can increase the reflectance of pavement by $30 \%$ thereby reducing the surface temperature and limiting the heat dissipated to the surrounding environment. Asaeda and Ca (2000), in Japan, observed that maximum mid-day temperatures of porous pavement were similar to those of vegetated soil and almost $10{ }^{\circ} \mathrm{C}$ less than the temperature of asphalt pavement. Porous pavement can also

\section{IPABH}

Rev. Ambient. Água vol. 13 n. 4, e2187 - Taubaté 2018 
improve water drainage and reduce flood risk. Nevertheless, additional studies are needed to evaluate the durability and economic viability of these materials.

Regardless, municipalities must monitor heat intensity in order to evaluate urban environmental quality and to determine the effectiveness of mitigating measures. For this, it is important to plan multiple transects on a year round basis.

\section{CONCLUSIONS}

The thermal analysis of the city of Uberlandia via mobile transect showed that: (1) the methodology used in the study proved to be a quick and efficient way of conducting this type of monitoring, as it could be applied quickly and was relatively economical in several cities of the country where climatic data are limited; (2) night air temperatures increase proportionally with the percentage of soil covered by buildings, which characterizes the heat islands in urban centers; (3) the analysis of the transect data of the evaluated days showed that the urban heat islands were more intense in winter $\left(\Delta \mathrm{T}=2,2^{\circ} \mathrm{C}\right)$ than in summer $\left(\Delta \mathrm{T}=1,2^{\circ} \mathrm{C}\right)$ because of the reduction of the atmospheric vapor in winter (dry season) and because of the higher rate of radiative cooling that occurs in permeable areas, that is, in the areas without construction, thus characterizing the effect of surface coverage on heat islands.

\section{REFERENCES}

AMORIM, M. C. C. T.; DUBRUIL, V.; CARDOSO, R. S. Modelagem espacial da ilha de calor urbana em Presidente Prudente (SP) - Brasil. Revista Brasileira de Climatologia, v. 16, n. 1, p. 1-17, 2015. http://dx.doi.org/10.5380/abclima.v16i0.40585

ASAEDA, T.; CA, V. T. Characteristics of permeable pavement during hot summer weather and impact on the thermal environment. Building and Environmental, v. 35, n. 4, p. 363-375, 2000.

ERELL, E.; WILLIAMSON, T. Intra-urban differences in canopy layer air temperature at a mid-latitude city. International Journal of Climatology, v. 27, n. 9, p. 1243-1255, 2007. https://doi.org/10.1002/joc.1469

HART, M. A.; SAILOR, D. J. Quantifying the influence of land-use and surface characteristics on spatial variability in the urban heat island. Theoretical and Applied Climatology, v. 95, n. 3-4, p.397-406, 2009. https://doi.org/10.1007/s00704-008-0017-5

HEDQUIST, B. C.; BRAZEL, A. J. Urban, residential, and rural climate comparisons from mobile transects and fixed stations: Phoenix, Arizona. Journal of the Arizona-Nevada Academy of Science, v. 38, n. 2, p. 77-87, 2006. https://doi.org/10.2181/15336085(2006)38[77:URARCC]2.0.CO;2

HOYANO, A. Climatological uses of plants for solar control and effects on the thermal environment of a building. Energy and Building, v. 11, n. 1-3, p. 181-199, 1988. https://doi.org/10.1016/0378-7788(88)90035-7

JONSSON, P. Vegetation as an urban climate control in the subtropical city of Gaborone, Botswana. International Journal of Climatology, v. 24, n. 10, p. 1307-1322, 2004. https://doi.org/10.1002/joc.1064 
OKE, T. R. Canyon geometry and the nocturnal urban heat island: Comparison of scale model and field observation. International Journal of Climatology, v. 1, n. 3, p. 237-254, 1981. https://doi.org/10.1002/joc.3370010304

OKE, T. R. City size and urban heat island. Atmospheric Environment, v. 7, n. 8, p. 769-779, 1973. https://doi.org/10.1016/0004-6981(73)90140-6

RIZWAN, A. M.; DENNIS, Y. C. L.; LIU, C. A review on the generation, determination and mitigation of Urban Heat Island. Journal of Environmental Sciences, v. 20, n. 1, p. 120 128, 2008. https://doi.org/10.1016/S1001-0742(08)60019-4

SILVA, V. P. R.; AZEVEDO, P. V.; BRITO, R. S.; CAMPOS, J. H. B. C. Evaluating the urban climate of a typically tropical city of northeastern Brazil. Environmental Monitoring and Assessment, v. 161, n. 1-4, p. 45-59, 2010. https://doi.org/10.1007/s10661-0080726-3

STEWART, I. D. A systematic review and scientific critique of methodology in modern urban heat island literature. International Journal of Climatology, v. 31, n. 2, p. 200-217, 2011. https://doi.org/10.1002/joc.2141

SUN, C.; BRAZEL, A. J.; CHOW, W. T. L; HEDQUIST, B. C.; PRASHAD, L. Desert heat island study in winter by mobile transect and remote sensing techniques. Theoretical and Applied Climatology, v. 98, n. 3-4, p. 323-335, 2009. https://doi.org/10.1007/s00704009-0120-2

TOLEDO, F. S.; MAZZEI, K.; SANTOS, D. G. A green area index (GAI) in Uberlandia city, MG. Revista da Sociedade Brasileira de Arborização Urbana, v. 4, n. 3, p. 86-97, 2009.

WONG, N. H.; YU, C. Study of green areas and urban heat island in a tropical city. Habitat $\begin{array}{lllllll}\text { International, } & \text { v. } & 29, & \text { n. } & 3, & \text { p. } & 547-558,\end{array}$ https://doi.org/10.1016/j.habitatint.2004.04.008

YOKOBORI, T.; OHTA, S. Effect of land cover on air temperatures involved in the development of an intra-urban heat island. Climate Research, v. 39, n. 1, p. 61-73, 2009. http://www.jstor.org/stable/24870423 